\title{
The Challenges of Statecrafting in Nigeria: A Focus on Selected Anti-Corruption Public Policies and Institutions
}

\author{
Ojo-Eyitope Esther Anike ${ }^{1}$, Ojo Ademola Eyitope ${ }^{2}$ \\ ${ }^{1}$ Department of Peace and Security Studies, Institute of Peace, Security and Governance. Ekiti State University, Ado Ekiti, Nigeia \\ ${ }^{2}$ Physical Planning Unit, Federal University, Oye Ekiti, Nigeria
}

Email address:

ojconnect2@yahoo.com (Ojo-Eyitope E. A)

To cite this article:

Ojo-Eyitope Esther Anike, Ojo Ademola Eyitope. The Challenges of Statecrafting in Nigeria: A Focus on Selected Anti-Corruption Public Policies and Institutions. Journal of Political Science and International Relations. Vol. 2, No. 1, 2019, pp. 18-24.

doi: 10.11648/j.jpsir.20190201.13

Received: October 30, 2018; Accepted: March 17, 2019; Published: April 8, 2019

\begin{abstract}
Statecrafting as an informed and organised process of the state to ensure effective governance using the instrumentations of public policies, laws etc., executed by and through agencies/institutions of government cannot be underestimated. Effective governance is also in combatting corruption as a social problem in Nigeria with debilitating consequences on the growth and development of the country. By this, successive regimes in Nigeria have enacted several legislations and established institutional frameworks to tackle corrupt practices, but the menace remained endemic and unabating but continued to grow with sophistications. This paper attempt to explore the dynamic pursuit of anti-corruption campaigns in Nigeria via appraisal of two selected policies and institutions as a new approach to the scourge and discourse. It was discovered that anti-corruption policies and institutions are ridden with shortcoming not limited to static, old and passive laws and policies, inadequate autonomy of the institutions, political interference, illegitimacy of policies, paucity of fund etc. The paper concluded that statecrafting is unlimited to states' roles in providing and ensuring socioeconomic and infrastructural development alone but until governance ensures a system of public probity where the vulnerable poorest and weakest of the people enjoy and benefit what the invincible wealthiest and most powerful ones also enjoy. It recommended several further reforms and deliberate constitutional strengthening and empowerment of anti-corruption policies and institutions so that efficient and effective governance is entrenched in Nigeria's development.
\end{abstract}

Keywords: Anti-corruption, Public Institutions, Public Policies, Statecrafting and Reforms

\section{Introduction}

It is commonplace axiom that change is the thing in human society that is static. This historical axiom arguably is not restricted to socio-political institutions, aimed at good governance. In order words, this underscores the proposition of a definite responsibility and central reasons of government for the main purpose of governance [3]. These often attract a complicated series of events and decisions that set in motion an equally complex process of socio-political transformation. The retinue of efforts orchestrating changes and shifts in and from inertia, incessant and or as they occur or as needs arises, informs policies, programmes and laws that affects institutions of government and hence statecrafting.

It is established that Statecrafting informs processes inclusive of skills of identifying, analysing and mitigating state (society) problems and challenges through development and provision of suitable policies, systems, structures and opportunities by setting up plans and programmes to improve living standard, education, health, infrastructure etc [13, 23]. Distillable from this posit are statecrafting instrumentations such as policies, laws, plans and programmes in an administrative system(s), executed by and through institutions of government. Lofty as it may, it was asserted that a source of inertia and resistance to instruments of statecrating are institutions, seen as excessively static and likely to remain on the same path unless some effort is made to divert them [26].

The context of the Nigerian state in the phase of the new change agenda may not be far in divergence from populist assertions that 'New Institutionalism' approach to political 
life assumed inability to explain the desired change, being overly structuralize and does not grant purposeful actors a proper role $[1,13]$. The retinue of anti-corruption policies, laws, programmes and institutions by the government alludes to and underscores the desire of the governed and innate intent for good governance. Succinctly, the public procurement act, financial regulations in public service, whistle blowing policy, Economic and Financial Crime Commission, Independent Corrupt Practices Commission etc., are no small policy instruments and institutions respectively that pursues transparency and good public governance in Nigeria as obtainable in the international space.

Essentially, there is growing international and domestic consensus in development discourse on the damage that corruption can do to the poor, to economic growth, public integrity and governance. As agreed, corruption is a pandemic and global phenomenon but peculiar and endemic in many developing nations of African and Asian nations as reported in a number of studies [9, 15, 24]. The issue of its reminiscences at virtually every forum worldwide, may be due to troubling upsurge of corruption, uneasy doing business, translucent bureaucracy, slow movement of goods and services, elections irregularities and struggle for political office, favoritism and by extension nepotism, public procurement contract fraud, ghost workers syndrome among others $[15,24]$. These abysmal credentials are fallout of lapses and derelictions on the part of public institutions on most statecraft policies and programmes engineered and believed well formulated but were poorly implemented [10].

This paper therefore aim to identify sources, assess efforts, and inhibiting issues in the pursuit of anti-corruption campaigns in Nigeria via appraisal of policies dynamics and institutions as a new approach to tackling the menace of corruption. These focus on selected anticorruption policies and institutions as corruption seem to be a citizen of the world but with family population residing all over.

\section{Concept of Public Policies and Institutions in Statecrafting}

There appear to be inconsistencies in definition of public policy. Fenna, opined that "public policy is the disposition and deliberate action of government on any and every matter over which it exercises authority", while (Paki and Ebienfa) submitted that "public policy has to do with actions taken by public authorities" $[12,31]$. These views infer that public policy is the principle that underscores government actions with regard to specific issues consistent with the law, institutions and the governed. It may involve encouraging actions and behaviours through legislation and executive approved instructions, procedures and guidelines to achieve consistent outcomes of socio-economic system. Hill and Hupe underscored that policy formation concur in a cycle and does not reflect rigid reality, but appears to provide a powerful analytical tool of a process [17]. A policy cycle therefore attempts to indicate a process through formation, implementation and evaluation.

A policy may remain a paper tiger if not tested through implementation. However, institutions are deliberately created and reformed in order to achieve substantive ends and execute policies. The concept of institution is fundamentally human structure of rules and regulations. Adamolekun refers it to administrative structures within which the work of government is carried out [2]. Thoenig and Seth agreed that institutions are organisations that handle organisational affairs but may not necessarily be governmental $[35,37]$. From these positions, institutions are a process framework of structured human organization constituted by distinct set of material and symbolic resources, for discrete set of organizational activities, based on a set of rules. Public institutions are not only products of laws and execute orders but execute and performs via statecraft instruments - policies, laws and programmes - and control the state resources in order to achieve better results - good governance.

In Nigeria, it is fundamentally provides for act of statecrafting by the various levels of government - federal, state and local- evident in fundamental responsibilities to the people amongst which are and not limited to elimination of all forms of criminal matters and corruption, the provision of infrastructure, security of life, the socio-economic development etc., of the governed through the apparatus of the governments (Public institutions) [8].

\subsection{Issues in Anti-Corruption Public Policies and Institutions}

A schedule of many sustainable challenges facing Nigeria is corruption which comfortably enjoys a top rank with its attendant micro and macro consequences [19]. This has attracted some decisive retributory plans through initiation of public policies, the passage of laws and establishment of institutions aimed at combating corruption.

A simple characterization of this retinue of public policies/Law and Institutions may emerge as show in Table 1 below;

Table 1. Characterisation of Selected Policies and Institutions in Anti-Corruption in Nigeria.

\begin{tabular}{lll}
\hline CHARACTERISED & POLICIES/LAW & INSTITUTIONS \\
\hline Financial Corruption & & \\
& Money Laundering (Prohibition) Act & Economic And Financial Crimes Commission \\
& Criminal Code and Penal Code Laws. & Code Of Conduct Bureau \\
& Biometric Verification Number & Financial Intelligence Unit \\
& Treasury Single Account & \\
& Whistle Blowing Policy & \\
& Fiscal Responsibility Act & \\
\hline
\end{tabular}




\begin{tabular}{|c|c|c|}
\hline CHARACTERISED & POLICIES/LAW & INSTITUTIONS \\
\hline \multicolumn{3}{|l|}{ Civil/Social Corruption } \\
\hline & War Against Indiciplines & National Identity Management Commission. \\
\hline & Public Service Delivery Efficiency & SERVICOM UNIT \\
\hline & Civil Code Act & \\
\hline & Freedom Of Information Act.2010 & \\
\hline & Whistle Blowing Policy & \\
\hline \multicolumn{3}{|c|}{ Criminal Practices Corruption } \\
\hline & Admistration of Criminal Justice/ Criminal Code Act & Independent Corrupt Practices Commission \\
\hline & Public Procurement Act. 2007 & Nigerian Police Force/Security Agencies \\
\hline & $\begin{array}{l}\text { The Nigeria Extractive Industries Transparency Initiative } \\
\text { (NEITI) Act }\end{array}$ & Bureau Of Public Procurement \\
\hline & Money Luandering Act & $\begin{array}{l}\text { Code of Conduct Bureau (CCB). } \\
\text { The Technical Unit On Governance \& Anti-Corruption Reforms } \\
\text { (TUGAR) }\end{array}$ \\
\hline \multicolumn{3}{|c|}{ International Conventions and treaties. } \\
\hline & UN Conventions, & Ministries of Justice and Foreign Affairs \\
\hline & $\begin{array}{l}\text { The AU Convention, } \\
\text { The ECOWAS Protocol }\end{array}$ & Office of Intergovermental Affairs \\
\hline
\end{tabular}

Source: Author, 2019

\subsection{Challenges and Inhibiting Factors to Anti-Corruption Public Policies and Institutions}

The increasing incidence of corruption with impunity especially in the public realm is one of the major challenges of government and has therefore became a matter of public concern [20]. This has informed a review of the various anticorruption policies and laws existing in Nigeria, which reveal that the country has demonstrated concern for curbing corruption through diverse legislation but bedeviled by numerous and apparently insurmountable challenges.

Many experts/scholars have reported that such inhibiting factors informing the challenges are not limited to political interference from the state, obsolete policies/laws and practices, lack of adequate autonomy by establishing laws, inadequate funding for law enforcement, slow judicial process in the prosecution etc. For example, Ribadu alleged Mr Ibori (former governor of Delta State, Nigeria) tried to bribe him with $\$ 15 \mathrm{~m}$ in cash to drop the investigations into his affairs, unfortunately in pursuant of the case, Mr Ribadu was removed from office as head of the Economic and Financial Crimes Commission (EFCC) (an anti-corruption institution) [38]. Also, Presidential Committee on Police Reform Report (2008) reported that successive military regimes erroneously regarded the Nigeria Police as a rival power base (to the armed forces) and as such, undermines its capabilities and effectiveness in order to sustain their political hegemony. Mr. Ekpo Nta, former chairman, Independent Corrupt Practices and Other Related Offences Commission (ICPC), agreed that Nigeria is not deficient of relevant policies/laws to combat corruption but that the major challenge is the will to execute the laws.

As reported in the case of Biobaku v. Nigerian Police Force, Nigeria Law Report(1951) 20(30), the dictum of the court, based on section 98, Criminal Code, submitted that the crime of corruption in the Criminal and Penal Codes, applicable in Nigeria, covers only persons employed in the public service(excluding private sector employees), alluding to the inadequacy of the policies and laws. To Igbuzor, corruption has remained widespread and pervasive because of failure and passive response to modern accepted and tested strategies by institutions [28]. This alludes to, who argued that performance of public institution like Public Complaint Commission has been unimpressive because of its statutory limitations with regard to enforcement and the non-cooperative stance by public servants [30].

Idris asserted that very common to all public institutions are the cases of large under-funding, lack of operational facilities, low compliance with the national policy on equitable distribution etc., Federal Character Commission (FCC), ICPC, Code of Conduct Bureau (CCB) are good examples. Another factor of challenge is the common cases of conflicts of interest among the various institutions involved in anti-corruption crusade [20]. Nkagwe, submitted that major conflicts of interest can be observed in the relationship between or among various courts, ministry, departments and agencies (MDA), prosecuting institutions, law enforcement and security agencies [30]. This is evident in the conflicts that exist between the Attorney General of the Federation, EFCC, Department of State Security and ICPC under section 43 of the EFCC Act, 2005.

\section{Method}

This work reviewed relatedness of public policies and public institutions and hence characterised their challenges as they affect statecrafting in Nigeria. It purposefully adopted this non-probabilistic research design approach due to the nature of the study. It distinctively adopted the content analysis and review of the focused public institutions and the selected public policies using their published laws, operation guidelines, and literatures, archives and records on anticorruption across sectors between years 2000 to 2017. The reviews focused on their establishment, policy guidelines, inhibiting factors on anti-corruption, national public policies/laws and public institutions causing challenges to statecrafting etc. However, only two each of public policies/laws and public institutions were subsequently 
discussed below.

\subsection{Public Policies}

\subsubsection{Whistle Blowing Policies}

Whistle blowing may be pivoted on the pillars of primordial professional practice in attempting to apprehend a suspected criminal and the sporting practice of umpires to stop/start an action according to $[29,16]$. The convergence of these therefore is on abhorrence of unethical or illegal practices as applied to public institution, guaranteed by fundamental and moral obligation to protect common societal interests. Whistle blowing policy has proven to be effective in many parts of the world as a tool for anti-corruption. The policy was officially launched by the Federal Ministry of Finance on December 22, 2016, it has attracted a reported large cases escalating to over 3,000 investigations and the recovery of several billions of naira within eight months, while yet awaiting legislative backing. Thus, whistle blowing is risk-unrestricted and can entail direct and unanticipated consequences for the person raising a voice against some wrongdoing.

The scope of its application in public institution and governance is not limited to non- compliance with the Financial Regulations (FR), Public Procurement processes and procedures, misappropriation of public funds and assets, fraud and bribery, Diversion of revenues etc. However, (34), inferring from the challenges of the policy in other nations viz- a-viz the whistle blower, reveal huge implications amongst are;

i Vulnerability to organizational reprisal.

ii Unpreserved integrity of the process.

iii Stigmatization of the individuals who report unethical or fraudulent conduct.

iv Skepticism about the sincerity of the government

$\mathrm{v}$ Reluctant to participate in the program.

vi lack of clarity around the moral justification for whistle blowing

vii Underpinning legal and administrative framework for policy.

viii Inadequacy of provisions for the protection of the whistle blower.

ix Social effects of the policy on the whistle blower.

\subsubsection{Public Procurement Act}

With the increasing growth and global responsiveness to socioeconomic development and its attendant opportunities, transparency, competition and value for money in every public sector transaction, has required and attracted rules and requirements of law to regulate activities like the public procurement laws. The found large deficiencies of the use of the then 1958 extant Financial Regulations (FR) and circulars issued by the Minister of Finance, cases of massive corruption in the public sector and especially that Nigeria did not possess a public procurement law informed enactment of the Public Procurement Act (PPA) of $19^{\text {th }}$ June, 2007. The main purpose of the Act is to ensure economy, transparency, efficiency, fairness, competition and value for money in all aspects of public procurement and asset disposal. It also provides for the establishment of supervisory Institutions and operational structures for public procurement practices, defined scope, process, method, supervision, complaint mechanism, code of conduct and offences relating to Procurement of goods, works, services and disposal of assets at the federal level in Nigeria.

Jubrin el at., submitted that the main challenges of the law included [22]

i Limited transparency of procurement processes of MDA's

ii Shortage of technical competence and skills within MDAs.

iii Refusal of the National Assembly to submit to the provisions of the Act and regulation by the Bureau,

iv Poor ethical standards in the service,

$\mathrm{v}$ Continued supervision of procurement officers in some instances by persons with less procurement knowledge and skill and no sure will for change.

vi Low morals in the service, and

vii Lack of political will to proceed against some violators of the Act.

viiiIntegrity of personnel and failure of $\mathrm{MDA}^{\text {ec }} \mathrm{s}$ to grant access to information to requesters of information.

ix Human attitudinal challenges.

\subsection{Public Institution}

\subsubsection{The Economic and Financial Crimes Commission (EFCC)}

The Economic and Financial Crimes Commission (EFCC) was established by an Act of the National Assembly -EFCC Establishment Act, 2004 (EFCC, 2004). EFCC has powers, functions and responsibilities as the designated Financial Intelligence Unit (FIU) in Nigeria, with the responsibility of coordinating the various institutions involved in the fight against money laundering and enforcement of all laws dealing with economic and financial crimes. Specifically, section 46 of the Act, provides a distinction between economic crimes and financial crimes. Economic crimes are non-violent, criminal and illicit activity committed with the objective of earning wealth illegally, any form of fraud, money laundering, illegal oil bunkering, tax evasion etc., while financial crimes include crimes committed not only with the intention of getting financial benefits but they are targeted directly on funds and other financial instruments e.g. advance fee fraud, currency trafficking and counterfeiting. This forms the structure of the institution depicted in sections (6 and 7) of the Act thus;

(a) the General and Assets Investigation Unit;

(b) the Legal and Prosecution Unit

(c) the Research Unit

(d) the Administration Unit; and

(e) the Training Unit.

As expressed in the Commission's Zero Tolerance 2009 report, its major challenges include;

i Many stalled cases in courts.

ii Issue of underfunding by the government. 
iii Limited coverage of the activities of the commission nationwide due to fund and manpower.

iv Lack of adequate autonomy for commission in practice as provisions of section 39 of the EFCC Act.

These and many more informed the call for the establishment of special Anti-Corruption Courts for effective service delivery.

\subsubsection{Bureau of Public Procurement (BPP)}

The Public Procurement Act (2007) provides for the legal framework upon wish all procurement activities hinges. The law precisely provided for the regulatory and operational institutions of public procurement while spelling out their distinctive and respective composition, functions, powers and responsibilities. Theses organs are;

a Regulatory Organs.

i The National Council on Public Procurement (NCPP).

ii The Bureau for public procurement (BPP).

b Operational Organs.

i Tender Board

ii Procurement Planning Committee

iii Tender Evaluation Committee.

The operational organs are basically resident in the Procuring Entities (PE). This forms a tripod but stratified regulatory and supervisory levels of public procurement in Nigeria.

The BPP is the executory and regulatory organ for public procurement activities of the Federal Republic of Nigeria, subject to NCPP. PPA (2007) section 3-14, provides extensively on the establishment, Objectives, functions, powers, Headship and Staffing, funding and the legal capacity of the BPP. Specifically, the BPP has the 4 (Four) objectives stated in section 4 PPA (2007) including;

$\mathrm{i}$ The harmonization of existing government policies and practices on public procurement and ensuring probity, accountability and transparency in the procurement process.

ii the establishment of pricing standards and benchmarks;

iii Ensuring the application of fair, competitive, transparent. value-for money

iv Standards and practices for the procurement and disposal of public assets and services.

$\mathrm{v}$ The attainment of transparency, competitiveness, cost effectiveness and professionalism in the public sector procurement system.

Also (Section 5) provided 19 functions while section 6 makes provision for 12 powers for the Bureau.

\section{Results and Discussions}

Lack of adequate autonomy by establishing laws of the state anti-corruption agencies appears a common phenomenon and it is contrary to the views of theory of institutional autonomy. For example, the constitutional provision (under Sections 174 and 211) and the political nature of the powers and duties of the Attorney General of the Federation and Minister of Justice in Nigeria make the occupier vulnerable to interfere in the running of agencies. Babalola et al. described autonomy as protection from interference by government officials in the running of the public institutions, without which merit and effective performance is unachievable $[6,23,26]$. Provisions in the Anti-Corruption Statutes are static, old and passive to emerging trends and advancement in the society and technology relating to corrupt practices e.g. electronic and internet crimes(cybercrimes), money laundering etc. For example, the corruption case involving one John Yusuf, who was accused and convicted, under the Penal Code, of embezzlement of about 33 Billion Naira but sentenced to two years imprisonment or to pay a fine of a paltry sum of 250,000.00 Naira for each of the three count charges against him totaling 750,000 Naira was cited and described as ridiculous [4].

Some policies and also statutes are not precise but are conflicting, contradictory and hence weaken their efficiencies in combatting corruption where and when they occur. For example Courts have justified the immunity clause (under Section 308 of the Federal Constitution, 1999) under several corruption cases against certain public office holders. Again, a conflicting provision on power to investigate and prosecute arises under the ICPC Act, and the Nigeria Police Act. For instance, proviso Section 69, ICPC Act,: Nothing contained in this Act shall derogate from the powers of a Police officer to investigate any offence under the Act or to prosecute any person in respect of any such offence provided that the Police shall bring to the attention of the commission every case of bribery, corruption or fraud being investigated or prosecuted by them after the coming into force of this Act. And Police Act. Section 4 provides: "The Police shall be employed for the prevention and detection of crime, the apprehension of Offenders, the preservation of law and order, the protection of life and property and due enforcement of all law and regulations with which they are directly charged". From the provisions, the police power to prosecute core corruption related offences rather than being granted a criminal status is watered down. Subsequently, this is in contrast with what obtains in real practice.

The political nature and hence insecurity of tenure of office of public official of the Anti-Corruption Agencies e.g. ICPC, EFCC, contribute in hampering their effectiveness. Closed to that lamented, is the problem of inadequate manpower and issue of untrained Prosecutors leading to a good number of cases being lost and a criminal escapes justice and returns to old ways [21]. Poor funding is a common fatigue causality of the various anti-corruption agencies to curb corruption in Nigeria.

Ardzard argued severally that certain anti-corruption policies are not only weak but lacks legislative power e.g. whistle blowing policies, presidential executive orders etc., hence their inability to effectively bite [5]. Similarly, available punishment as provided and prescribed in statues book and policies on corruption are not profoundly excruciating to the extent of serving as deterrence to further 
corruption prospects. For example the EFCC (Enforcement) Regulations, 2010 (in Paragraph 22 (1) and (2)) permits, subject to the approval of the Attorney General of the Federation, to enter into a plea bargain with an accused, who proposes or signifies interest. However, this can rightly be described as a soft landing granted an accused to proceed on retention and enjoy the part of the corruption proceeds and while under light sentences and lived happily thereafter. Again, Bello-Imam found that the citizens' perception of anti-corruption fight and prosecution are selective [7].

\section{Conclusion and Recommendations}

This paper has clearly revealed that public policies and institutional reforms can have positive impact on governance across economy sectors. The crux of statecrafting is unlimited to the roles of government and stakeholder groups toward providing and ensuring socio economic and infrastructural development of the nation. It is evolving to appreciating that a nation state and its governance is only truly democratic when the vulnerable poorest and weakest of the people enjoy and benefit what the invincible wealthiest and most powerful ones also enjoy. In emphasis, the central reason for government in any human society is to ensure fair state dealings relatively devoid of inequalities of common resources by way of ensuring and instituting frameworks that will combat challenges especially corruption and its attendant vices. The instruments of reforms through processes of institutional and system development and implementation of suitable public policies, laws structure and opportunities referred become handy.

In view of the import of this, it's recommended as follows;

1. Streamlining the operations of the public agencies must be addressed in order to optimize state resources in the course of achieving common goal.

2. Relevant public agencies related to anti-corruption be reduced to make supervision and control easier. This may involve harmonization of existing government policies and practices towards ensuring probity, accountability and transparency.

3. Abilities and capacities of anti-corruption agencies should be strengthened through improved funding and support from the government to enable optimal performance.

4. Particular focus on citizens' involvement in national anti-corruption discourse should be encouraged deliberately across age groups, community associations, professional circle etc.

5. Improved funding of state anti-corruption agencies must be prioritized by the government for their performance.

6. Amendments to some of the anti-corruption statutes to cure the shortcomings, weaknesses and limitation are serious and urgently required.

7. Provisions in statutes books with respect to forfeiture office and personal liability of actions and inactions by any Public Officer or Officials of public and private corporate entities who are charged to Court on corruption offences pending the conclusion of their trial.

\section{References}

[1] Adamolekun, L., (1999). Public administration in Africa: Main issues and selected country studies Westview, Boulder, CO.

[2] Adamolekun, L. (2002). Central Government Organisation. Adamolekun, L. (ed), Public Administration in Africa, Main Issues and Selected Country Studies. Spectrum Books Limited, Ibadan (3-6).

[3] Agh, A. (2003). 'Public administration in Central and Eastern Europe', in B. G. Peters and J. Pierre (eds), Handbook of Public Administration, London: Sage, pp. 526-548.

[4] Alubo, A. O. et al. (2013) In: Abdulkadir, I. A. et al (eds.) Corruption and National Development: Proceedings of the 46th Annual Conference of the Nigerian Association of Law Teachers. Nigerian Association of Law Teachers, Nigeria, p. 263.

[5] Ardzard H. S. (2017). The Legal And Institutional Measures In Combating Corruption In Nigeria: Issues, Challenges And Prospects. unpublished Postgraduate Thesis Submitted In Partial Fulfillment of the Requirements for the Award of the Degree of Doctor of Philosophy (Phd) In Law. Ahmadu Bello University, Zaria. February.

[6] Babalola, J. B., Jaiyeoba, A. O; and Okediran, A. (2007). University autonomy and financial reforms in Nigeria: Historical background, issues and recommendations from experience. In J. B. Babalola and B. O. Emunemu (eds). Issues in Higher Education: Research evidence from subSaharan, Africa. Lagos: Bolabay publications.

[7] Bello-Imam I. B., (2005). The War Agaisnt Corruption in Nigeria: Problems and Prospects, Ibadan, College Press \& Publishers.

[8] The Constitution of the Federal Republic of Nigeria 1999 as amended.

[9] Dike, V. E. (2001). Corruption in Nigeria: a new paradigm for effective control. Africa Economic Analysis, 24-29. Eyaa S, Oluka P (2011). Explaining Non- Compliance In Public Procurement In Uganda. International Journal of Business and Social Science 2 (11) 23-34.

[10] Egonmwan, J. (2004). Public Policy: Concepts and Applications. Benin City: S. M. O Aka and Brother Press. Dike, V. E. (1999). The philosophy of Transforming Nigeria into a Corruption-free Society: Are the probes the Solution? Retrieved on 6 October 2010 from Nigeriaworld.com/feature/article/corruption.html.

[11] Eyaa S and Oluka P (2011). Explaining Non- Compliance In Public Procurement In Uganda. International Journal of Business and Social Science June 2 (11)7-14

[12] Fenna, A. (2004). Australian Public Policy, 2nd Edition. Frenchs Forest, NSW: Pearson Education.

[13] Federal Character Commission FCC http://www.federalcharacter.gov.ng/mtsschapterthree.php date accessed 7/4/2013. 
[14] Greif, A. and D. D. Laitin (2004). 'Theories of endogenous institutional change', American Political Science Review 98(4): 633-652.

[15] Gurgur, T. and Anwar, S. (2005). Localization and Corruption: Panacea or Pandora's Box. World Bank Policy Research Working Paper 3486.

[16] Hoffman, W. M \& McNulty, R. E (2010). A Business Ethics Theory of Whistleblowing: Responding to the $\$ 1$ trillion question. In M. Arszulowicz (Ed.), Whistleblowing: In Defense of Proper Action (pp. 45-59). New York: Transaction Publishers.

[17] Hill, M and Hupe, P. (2003) "The Multi-layer problem in implementation research" Public Management Review, Vol. 5(4), pp. $471-490$.

[18] Corrupt Practices and Other Related Offences Act, Cap C31, LFN, 2004.

[19] Ikpeze N. (2013). Afe Babalola University: Journal of Sustainable Development Law and Policy Vol. 1 Iss. 1 (2013) pp. 148-167

[20] Idris M. (2011). Assessment Of The Effectiveness Of AntiCorruption Institutions In The Federal Public Service Of Nigeria. An unpublished Phd Dissertation, Submitted To The Department Of Public Administration Ahmadu Bello University, Zaria Nigeria. October.

[21] Kwede, F. M. (2014) Administration of Justice: The Plateau State Experience. In Kwede, F. M. (ed.) Contemporary Issues in Law and Administration of Justice in Nigeria, Hamtul Press Ltd. Jos, p. 23.

[22] Jibrin S., Ejura B., and Nwaorgu I. (2014). The Public Procurement Reforms in Nigeria: Implementation and Compliance Challenges. Journal of Asian Business Strategy, 4(11)2014: 149-162.

[23] Nchi, S. I. and Wada, T. U. (2004). Powers And Duties Of The Attorney General In Nigeria. Green World Publishing Co. Ltd, Jos, p. 84.

[24] Ojo A. E. (2012). Statecraft Engineering and Public Infrastructures. Hope Newspapers, Hope Publisher. Pp.34.

[25] Ojo, A. E. and Ojo, A. C (2012). Corruption in Poor and Rich Nations: A Comparative Review. Social and Management Research Journal. 9 (1).

[26] Ojedele, P. and Ilusanya, G. (2006). Planning and policy of higher education in Nigeria. In J. B. Babalola, A. O. Ayeni, S. O. Adedeji, A. A. Suleiman and M. O. Arikewuyo (eds) Educational Management: Thoughts and Practice. Ibadan. Codat publications.

[27] Olsen J. P. ( $\left(\begin{array}{lll}2 & 0 & 0\end{array}\right)$. Changeand Continuity: An Institutional Approach To Institutions Of Democratic Government. Eurpean Political Science Review.1(1) 3 - 32.

[28] Igbuzor O. (2016). The Buhari Administration and War against Corruption in Nigeria. Retrieved on $03 / 11 / 2017$ on http://www.otiveigbuzor.com.

[29] Miceli, M. P \& Near, J. P (1992). Blowing the Whistle: The Organizational and Legal Implications for Companies and Employees. New York: Lexington Books.

[30] Ngakwe, E C (2009) 'An Analysis of Jurisdictional Conflicts among anti-corruption Laws and Institutions in Nigeria' in D. U. Enweremadu and E. E. Okafor (eds), Anti-Corruption Reforms in Nigeria since 1999: Issues, Challenges and the Way Forward, IFRA Special Research Issue Vol. 3, Ibadan, p..8.

[31] Paki F. A and Ebienfa K. I. (2011). Public Policy In Nigeria: An Implementation Paradox. Journal of Social Science and Public Policies. March Vol.2.

[32] Police Act Cap P. 19 LFN, 2004.

[33] Presidential Committee on Police Reform Report(2008).

[34] Taiwo, S. F. (2015). Effects of Whistle Blowing Practices on Organizational Performance in the Nigerian Public Sector: Empirical Facts from selected Local Government in Lagos \& Ogun State. Journal of Marketing and Management, 6 (1), 4161 .

[35] Thoenig, J. C. (2007). Institutional Theories and Public Institutions; Tradition and Appropriateness . In; Peter, B. G. Pierre, J. (eds), Handbook of Public Administration. Sage Publications, London.

[36] The Nigerian Constitution (1999), Sections 10, 169, 171, 208 and 318.

[37] Seth, A. (2008). A General Theory of Institutional Autonomy. Retrieved on 11/23/2008 from http://www. allacademic.com.

[38] Ribadu N., (2006) "Combatting Money Laundering in Emerging Economies: Nigeria as a Case Study", Guest Lecture Series, Financial Institutions Training Centre/Nigerian Institute of International Affairs, Lagos, August 10. 